\title{
MAPPING OF HEAVY METAL CONTAMINATION IN ALLUVIAL SOILS OF THE MIDDLE NILE DELTA OF EGYPT
}

\author{
Mohamed S. SHOKR ${ }^{\mathrm{a}, \mathrm{b}}$, Ahmed A. EL BAROUDY, Michael A. FULLEN ${ }^{\mathrm{b}}$, Talaat R. EL-BESHBESHY, \\ Ramadan R. ALIc, Abd ELHALIM ${ }^{\mathrm{a}}$, Antonio J. T. GUERRA ${ }^{\mathrm{d}}$ and Maria C. O. JORGE ${ }^{\mathrm{d}}$ \\ ${ }^{a}$ Soils and Water Department, Faculty of Agriculture, Tanta University, Tanta, Egypt \\ ${ }^{b}$ The University of Wolverhampton, Wolverhampton WV1 1LY, UK \\ 'Soils and Water Use Department, National Research Centre, Giza, Egypt \\ ${ }^{d}$ Department of Geography, Federal University of Rio de Janeiro, Brazil
}

Submitted 08 Dec. 2015; accepted 26 Apr. 2016

\begin{abstract}
Areas contaminated by heavy metals were identified in the El-Gharbia Governorate (District) of Egypt. Identification used remote sensing and Geographical Information Systems (GIS) as the main research tools. Digital Elevation Models (DEM), Landsat 8 and contour maps were used to map physiographic units. Nine soil profiles were sampled in different physiographic units in the study area. Geochemical analysis of the 33 soil samples was conducted using X-ray fluorescence spectrometry (XRF). Vanadium (V), nickel (Ni), chromium $(\mathrm{Cr})$, copper $(\mathrm{Cu})$ and zinc $(\mathrm{Zn})$ concentrations were measured. $\mathrm{V}, \mathrm{Ni}$ and $\mathrm{Cr}$ concentrations exceeded recommended safety values in all horizons of the soil profiles, while $\mathrm{Cu}$ had a variable distribution. $\mathrm{Zn}$ concentrations slightly exceeded recommended concentration limits. Concentrations were mapped in each physiographic unit using the inverse distance weighted (IDW) function of Arc-GIS 10.1 software. Pollution levels were closely associated with industry and urban areas.
\end{abstract}

Keywords: soil contamination, $\mathrm{x}$-ray fluorescence spectrometry, remote sensing, geographical information systems, Middle Nile Delta, Egypt.

\section{Introduction}

Sustainable agriculture is mainly related to environmental, agronomic, ethical and socio-economic issues (Abd Elgawad et al. 2007). One aspect of sustainability is accumulation of heavy metals in soils, which may cause serious problems, if certain levels are exceeded. In recent years, much concern has been articulated over problems of soil contamination with heavy metals. These metals can accumulate in plants and animals and then in humans through the food chain (Govil et al. 2001; Lu, Bai 2010; Romic, M., Romic, D. 2003). Thus, heavy metals may damage human health and the environment (Jankaite, Vasarevičius 2005).

The Nile Delta (area $\sim 20,000 \mathrm{~km}^{2}$ ) represents only $2.3 \%$ of the area of Egypt, but it has $\sim 46 \%$ of the total cultivated area $\left(55,040 \mathrm{~km}^{2}\right)$ and accommodates $\sim 45 \%$ of Egypt's population (Fanos 2002), with densities $\leq 1600$ inhabitants per $\mathrm{km}^{2}$ (Zeydan 2005). On the Nile Delta $~ 63 \%$ land is agricultural, due to suitable soil properties and the presence of irrigation systems (Dawoud 2004). The River Nile divides into two branches, the Rosetta and Damietta, and the Delta region is located between them (Dumont 2009). The Nile Delta (area 404,686 ha) depends on drainage water for irrigation (Abu 2011).

There are three major layers in the middle Delta aquifer (Atwia et al. 2006). The uppermost layer is composed of clay deposits, the second layer is formed from sandy clay deposits and the third layer is composed of saturated sand and gravel. Thus, the thin clay layers and presence of sandy clay lenses facilitate percolation of sewage water to the aquifer. Many activities, including agricultural development and industrial activities and inadequate rural sanitation, have impacts on eutrophication and contamination status, ecological value and environmental conditions in the Nile Delta (Zeydan 2005).

Heavy metal contamination of soil may present risks and hazards to humans and the ecosystems through: direct consumption or contact with contaminated soil, the food chain (soil-plant-human or soil-plant-animalhuman), drinking of contaminated ground-water, decreased food quality (safety and marketability) via

Corresponding author: Mohamed Shokr

E-mail:m.s012@yahoo.com 
phytotoxicity, reduction in land usability for agricultural production causing food insecurity, and land tenure problems (McLaughlin et al. 2000; Ling et al. 2007). Huge amounts of fertilizers are regularly added to soils in intensive farming systems to provide sufficient nitrogen $(\mathrm{N})$, phosphorus (P) and potassium (K) for crop growth. The compounds used to supply these elements contain trace amounts of heavy metals which, after continued fertilizer application, may significantly increase soil metal contents (Raven et al. 1998). Integration of remote sensing information within a GIS database can quickly provide detailed soil survey information at low cost. GIS databases can also help derive Digital Elevation Models (DEM), which can help derive landscape attributes utilized in landform characterization (Brough 1986; Dobos et al. 2000).

It is critical to analyse the distribution and concentration of metals. This will enable identification of contamination levels and assess associated impacts, on both the environment and human health. Soils are a vital sink for these metals, because of their high metal retention capacities. The assessment and mapping of soil heavy metals can assist the development of strategies to promote sustainable use of soil resources, decrease soil degradation and expand crop production. Remediation of soils polluted by heavy metals is a major global ecological issue. Remote sensing is one of the most important methods used for soil survey, mapping and environmental investigations (Lillesand, Kiefer 2003). Geostatistical interpolation is used to survey and interpret the spatial distribution of pollutants in soil (He, Jia 2004; Woo et al. 2009). The inverse distance weighted (IDW) function is helpful when the purpose is to investigate overall pollution patterns (Zheng 2006). The Middle Nile Delta is affected by different pollution sources, because of the increasing number and types of industries, urban expansion, increased traffic volumes, use of drain-water and waste deposits (Abu Khatita 2011). The latter may well present a long-term danger. Usually waste deposits just settle within the normal Nile sediments and no special effort is made to construct barriers, which hinder the migration of water from these deposits into ground-water. High concentrations of vanadium (V) can damage human health, while the inhalation of airborne V-compounds can affect eyes, throat and lungs, produce weakness, ringing in the ears, nausea, vomiting, headaches and damage nerve systems (Lagerkvist, Oskarsson 2007). In Egypt, measured chromium (Cr) contents in soils range between 11.6-179 ppm, and depend on soil types and land management (Abdel-Sabour et al. 2002). Cr toxicity depends on its oxidation status. While $\mathrm{Cr} 3^{+}$is considered relatively harmless, $\mathrm{Cr}^{+}$is highly toxic. Cr uptake can cause diarrhoea, bleeding in the stomach and intestines, liver and kidney damage and cramp. Nickel $(\mathrm{Ni})$ compounds are relatively non-toxic for plants and animals, but there is an increased risk of respiratory tract cancer, due to exposure to nickel sulphide and oxides (Sundermann, Oskarsson 1991).

Copper $(\mathrm{Cu})$ is an essential element for all life-forms. In plants, $\mathrm{Cu}$ is required in small amounts $(5-15 \mathrm{ppm})$ (Bowen 1979). The amount of $\mathrm{Cu}$ in soils may affect crop growth and yields. The application of $\mathrm{Cu}$ salts to $\mathrm{Cu}$-deficient soils increases crop yields, because it compensates for $\mathrm{Cu}$ deficiency in plants (Baker, Senft 1995). Coal flyash contains $48 \mu \mathrm{g} / \mathrm{g}$ of $\mathrm{Cu}$ (Wong, M. H.; Wong, J. W. C. 1986). In Ohio (USA), measured $\mathrm{Cu}$ concentrations in indoor dust were twice that of outdoor dust (Tong 1998). $\mathrm{Cu}$ toxicity in humans is relatively rare, because they can tolerate levels $\leq 12 \mathrm{mg} /$ day (WHO 1996). However, Cu deficiency in humans causes anaemia, bone and cardiovascular disorders, mental and nervous system deterioration and defective keratinization of hair.

Zinc $(\mathrm{Zn})$ is the fourth most used metal in the world, after iron (Fe), aluminium ( $\mathrm{Al}$ ) and $\mathrm{Cu}$ (Bradl, Xenidis 2005). $\mathrm{Zn}$ uptake can lead to health disorders, including pancreatic diseases. Inhalation of $\mathrm{Zn}$-oxide (particle size 0.2-1 $\mu \mathrm{m}$ ) during $\mathrm{Zn}$-processing causes metal fume fever, which is characterized by a sore throat, cough, fever, vomiting and pneumonitis (Ohnesorge, Wilhelm 1991).

The main aim of this research is to identify land contaminated by heavy metals in the El-Gharbia Governorate (District) of Egypt. This was undertaken using remote sensing, Geographical Information Systems (GIS) and Xray fluorescence (XRF) spectrometry (Fig. 1).

\section{Materials and methods}

\subsection{Study area}

The study area occupies the Middle part of the Nile Delta of Egypt. It is bounded by $30^{\circ} 45^{\prime} 20^{\prime \prime}-31^{\circ} 10^{\prime} 50^{\prime \prime} \mathrm{E}$ and $30^{\circ} 35^{\prime} 10^{\prime \prime}-31^{\circ} 10^{\prime} 05^{\prime \prime} \mathrm{N}$, and covers an area of $1927.4 \mathrm{~km}^{2}$ (Fig. 2). Based on the US Soil Taxonomy (USDA 2010) the soil temperature regime of the study area is Thermic and the soil moisture regime is Torric. The mean annual

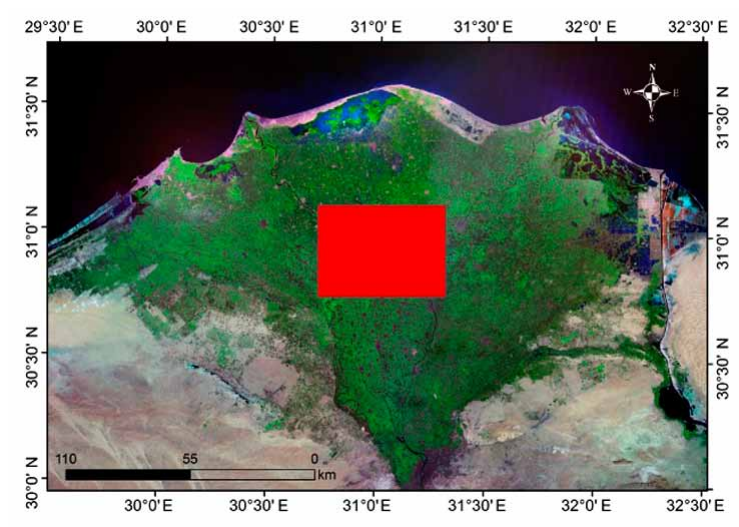

Fig. 1. Location of the study area in the middle Nile Delta of Egypt. - study area 


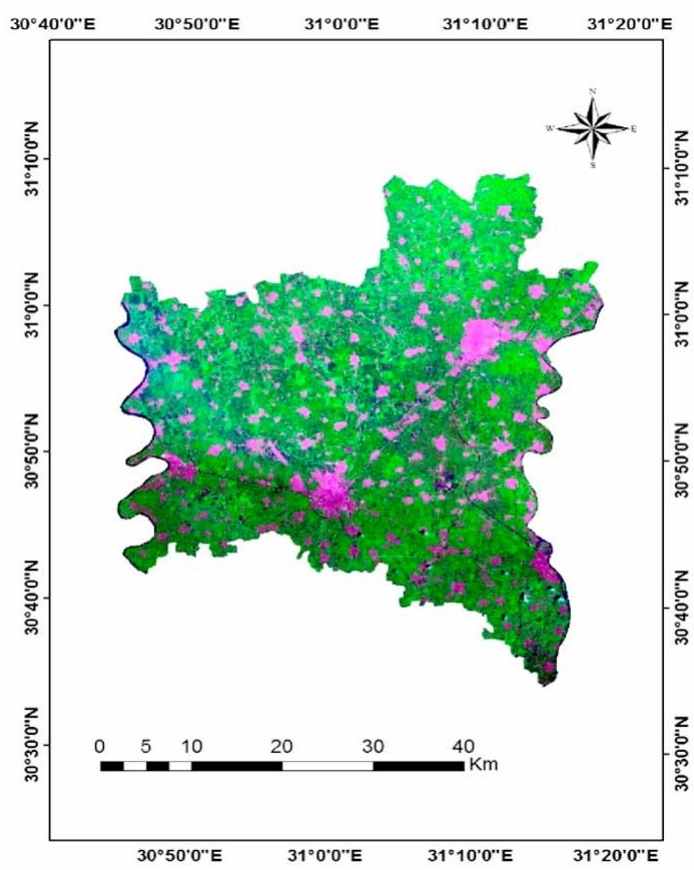

Fig. 2. Landsat 8 mosaic of the study area

temperature reaches its maximum in June, July and August and often exceeds $30^{\circ} \mathrm{C}$. The mean minimum temperature $\left(11.2^{\circ} \mathrm{C}\right)$ usually occurs in January, February or March at Tanta Meteorological Station (Climatologically Normal for Egypt 2011). Precipitation is unequally distributed through the rainy season. Annual rainfall is very low and mostly falls in winter; with a mean $3.8 \mathrm{~mm}$ /year. Rain mainly falls in the cold season (November-March) and the minimum amount is in June and September. The area belongs to the late Pleistocene era, which is evidenced by the deposits of the Neonile, which are composed of medium and fine silts (Said 1993).

\subsection{Digital image processing and physiographic mapping}

Digital image processing was completed for two Landsat 8 satellite images (path 177/row 38 and path 177/row 39), with a spatial resolution of $30 \mathrm{~m}$, acquired in May 2014. The images were pre-processed, including radiometric correction (used to modify digital values of pixels to remove noise). Images were geometrically rectified using the Universal Transverse Mercator (UTM) co-ordinates, with the World Geodetic System datum (WGS 1984) and then maps were constructed. Images were atmospherically corrected using the FLAASH module (ITT 2009). Data were calibrated to radiance using the inputs of image type, acquisition date and time. Images were subject to linear stretching by $2 \%$, smooth-filtered, and their histograms were matched, adopting the procedures of Lillesand and Kiefer (2007) and mosaicked using ENVI 5.1 software. The extraction of landform units used high spatial resolution images, so the spatial resolution of satellite image was enhanced using the data merge function of Envi5.1 software. Merging is performed by using multispectral bands $(\sim 30 \mathrm{~m})$ as low spatial resolution, and band 8 (panchromatic band) with $\sim 15 \mathrm{~m}$ resolution. Landforms were extracted using contour maps (scale 1:25,000) and enhanced satellite images. Both enhanced satellite images were processed with DEM in ERDAS Imagine 8.7, to extract the landform information (Dobos et al. 2002). The initial landform maps were ground-truthed using field observations.

\subsection{Spatial distribution of heavy metals}

Spatial interpolation is widely used when data are collected at distinct locations (e.g. soil profiles) for producing continuous information (Ali, Moghanm 2013). Inverse distance weighted (IDW) is an interpolation method which uses measured values surrounding the prediction location. The measured values closest to the prediction location have more influence on the predicted value than those farther away, thus giving greater weight to points closest to the prediction location, and the weights decrease as a function of distance (Shepard 1968). Geostatistical relationships among the known points (IDW) of Arc-GIS 10.1 software were used to interpolate heavy metal concentrations in the study area. The spatial interpolation method (IDW) was used with 12 neighbouring samples for estimation of each grid point. A power of two was used to weight the nearest points.

\subsection{Assessment of contamination risk}

The Geoaccumulation Index (Igeo) was originally used to evaluate bottom sediment contamination. However, it has been successfully used to evaluate soil contamination (Gowd et al. 2010). The Igeo Index means the assessment of contamination depends on comparing heavy metal concentrations in soils to background values. The calculation of the Geoaccumulation Index uses the equation:

$$
\text { Igeo }=\log 2 \frac{C_{n}}{1.5 B_{n}},
$$

where $C_{n}=$ the measured concentration of the element in soil; $B_{n}=$ the geochemical background concentration of the heavy metal.

The Geoaccumulation Index (Igeo) is shown in Table 1.

\subsection{Soil analysis}

Soil samples were collected from nine profiles in ElGharbia Governorate. The selected profiles represent the different soil units. Pedological descriptions of profiles were conducted using the procedures of FAO (2006) (Table 2). About $1 \mathrm{~kg}$ was collected from each horizon of 
Table 1. The Geoaccumulation Index (Igeo) for assessing contamination levels in soil (Rahman et al. 2012)

\begin{tabular}{ccl}
\hline Igeo Class & Igeo value & \multicolumn{1}{c}{ Contamination level } \\
\hline 0 & Igeo $\leq 0$ & Uncontaminated \\
\hline 1 & $0<$ Igeo $<1$ & $\begin{array}{l}\text { Uncontaminated/moderately } \\
\text { contaminated }\end{array}$ \\
\hline 2 & $1<$ Igeo $<2$ & Moderately contaminated \\
\hline 3 & $2<$ Igeo $<3$ & $\begin{array}{l}\text { Moderately/strongly } \\
\text { contaminated }\end{array}$ \\
\hline 4 & $3<$ Igeo $<4$ & Strongly contaminated \\
\hline 5 & $4<$ Igeo $<5$ & Strongly/extremely contaminated \\
\hline 6 & $5<$ Igeo & Extremely contaminated \\
\hline
\end{tabular}

each profile. Soil samples were air-dried and large stones and organic debris were removed before sieving. Samples were gently ground, homogenized, sieved through a 2.0 $\mathrm{mm}$ sieve and then crushed to a fine $(<125 \mu \mathrm{m})$ powder. Oven-dry samples were ignited at $375^{\circ} \mathrm{C}$ for 16 hours (overnight), adopting the procedures of Ball (1964). Subsamples of $8.5 \mathrm{~g}$ of soil powder were added to $1.5 \mathrm{~g}$ of wax (Lico waxc micropowder PM, Hoechst wax)) and then compressed under 12 tonnes pressure by a semi-automatic hydraulic press to make a pellet. The geochemical composition of soil pellets were analysed using an XRF spectrometer model Epsilon3 XLE. XRF analyses were performed at the University of Wolverhampton, UK.

Table 2. Pedological descriptions of soil profiles

\begin{tabular}{|c|c|c|c|c|c|}
\hline $\begin{array}{c}\text { Profile } \\
\text { Number }\end{array}$ & Depth $(\mathrm{cm})$ & Colour & Texture & Structure & Soil consistency \\
\hline \multirow{4}{*}{1} & $0-50$ & $\begin{array}{l}\text { 5YR 3/4 } \\
5 \text { YR5/4 }\end{array}$ & Loam & Sub-angular blocky & Sticky, plastic \\
\hline & $50-85$ & $\begin{array}{l}7.5 \text { YR } 5 / 6 \\
7.5 Y R ~ 6 / 6\end{array}$ & Sandy loam & Sub-angular blocky & Slightly sticky, slightly plastic \\
\hline & $85-120$ & $\begin{array}{l}\text { 10YR 5/8 } \\
10 Y R 6 / 8\end{array}$ & Loam & Sub-angular blocky & Sticky, plastic \\
\hline & $120-150$ & $\begin{array}{l}10 Y R 5 / 8 \\
10 Y R ~ 7 / 8\end{array}$ & Sandy loam & Sub-angular blocky & Slightly sticky, slightly plastic \\
\hline \multirow{3}{*}{2} & $0-45$ & $\begin{array}{l}5 Y R 4 / 6 \\
5 Y R \text { 5/6 }\end{array}$ & Sandy Loam & Sub-angular blocky & Slightly sticky, slightly plastic \\
\hline & $45-85$ & $\begin{array}{l}10 Y R \text { 5/8 } \\
10 Y R 6 / 8\end{array}$ & Sandy Clay Loam & Sub-angular blocky & Sticky, plastic \\
\hline & $85-110$ & $\begin{array}{l}10 \text { YR } 5 / 8 \\
10 \text { YR } 7 / 8\end{array}$ & Sandy Loam & Sub-angular blocky & Slightly sticky, slightly plastic \\
\hline \multirow{3}{*}{3} & $0-75$ & $\begin{array}{l}10 \text { YR 5/6 } \\
10 \text { YR 6/8 }\end{array}$ & Sandy Loam & Sub-angular blocky & Slightly sticky, slightly plastic \\
\hline & $75-100$ & $\begin{array}{l}10 Y R \text { 5/6 } \\
10 Y R ~ 7 / 8\end{array}$ & Loam & Sub-angular blocky & Sticky, plastic \\
\hline & $100-150$ & $\begin{array}{l}10 Y R \text { 5/8 } \\
10 Y R ~ 7 / 8\end{array}$ & Silt loam & Sub-angular blocky & Sticky, plastic \\
\hline \multirow{4}{*}{4} & $0-60$ & $\begin{array}{l}5 Y R \quad 4 / 8 \\
5 Y R 4 / 6\end{array}$ & Loam & Sub-angular blocky & Sticky, plastic \\
\hline & $60-100$ & 10 YR $5 / 8$ & Sandy Loam & Sub-angular blocky & Slightly sticky, slightly plastic \\
\hline & $100-120$ & 10YR 7/6 & Loam & Sub-angular blocky & Sticky, plastic \\
\hline & $120-150$ & $\begin{array}{l}5 Y R 4 / 8 \\
5 Y R \quad 4 / 6\end{array}$ & Sandy Loam & Sub-angular blocky & Slightly sticky, slightly plastic \\
\hline \multirow{4}{*}{5} & $0-45$ & $\begin{array}{l}10 Y R \text { 5/8 } \\
10 Y R ~ 7 / 8\end{array}$ & Sandy Loam & Sub-angular blocky & Slightly sticky, slightly plastic \\
\hline & $45-65$ & $\begin{array}{l}7.5 \text { YR 5/6 } \\
7.5 \text { YR 5/8 }\end{array}$ & Loam & Sub-angular blocky & Sticky, plastic \\
\hline & $65-110$ & $\begin{array}{l}10 Y R \text { 5/8 } \\
10 Y R 6 / 8\end{array}$ & Silt loam & Sub-angular blocky & Sticky, plastic \\
\hline & $110-150$ & $\begin{array}{l}10 \text { YR } 5 / 8 \\
10 \text { YR } 6 / 8\end{array}$ & Sandy Loam & Sub-angular blocky & Slightly sticky, slightly plastic \\
\hline 6 & $0-35$ & $\begin{array}{l}\text { 10YR 5/6 } \\
10 \text { YR } 6 / 8\end{array}$ & Sandy Loam & Sub-angular blocky & Slightly sticky, slightly plastic \\
\hline
\end{tabular}


End of Table 2

\begin{tabular}{|c|c|c|c|c|c|}
\hline $\begin{array}{l}\text { Profile } \\
\text { Number }\end{array}$ & Depth $(\mathrm{cm})$ & Colour & Texture & Structure & Soil consistency \\
\hline \multirow{3}{*}{6} & $35-65$ & $\begin{array}{l}10 \text { YR } 6 / 8 \\
10 \text { YR } 7 / 8\end{array}$ & Loam & Sub-angular blocky & Sticky, plastic \\
\hline & $65-100$ & $\begin{array}{l}10 \text { YR } 5 / 8 \\
10 \text { YR } 7 / 8\end{array}$ & Loam & Sub-angular blocky & Sticky, plastic \\
\hline & $100-150$ & $\begin{array}{l}5 \text { YR 5/6 } \\
5 Y R \quad 4 / 8\end{array}$ & Sandy Loam & Sub-angular blocky & Slightly sticky, slightly plastic \\
\hline \multirow{3}{*}{7} & $0-55$ & $\begin{array}{l}5 \text { YR 4/8 } \\
5 Y R \text { 6/8 }\end{array}$ & Sandy Loam & Sub-angular blocky & Slightly sticky, slightly plastic \\
\hline & $55-110$ & $\begin{array}{l}\text { 5YR } 4 / 8 \\
5 \text { YR } 6 / 8\end{array}$ & Loam & Sub-angular blocky & Sticky, plastic \\
\hline & $110-150$ & $\begin{array}{l}7.5 \text { YR 5/8 } \\
7.5 \text { YR } 6 / 4\end{array}$ & Sandy Loam & Sub-angular blocky & Slightly sticky, slightly plastic \\
\hline \multirow{4}{*}{8} & $0-30$ & $\begin{array}{l}7.5 \text { YR } 4 / 4 \\
7.5 Y R \text { 5/8 }\end{array}$ & Silt loam & Sub-angular blocky & Sticky, plastic \\
\hline & $30-60$ & $\begin{array}{l}7.5 \text { YR } 4 / 6 \\
7.5 \text { YR } 6 / 8 \\
\end{array}$ & Silt loam & Sub-angular blocky & Sticky, plastic \\
\hline & $60-100$ & $\begin{array}{l}7.5 \text { YR } 5 / 8 \\
7.5 \text { YR } 6 / 8 \\
\end{array}$ & Silt loam & Sub-angular blocky & Sticky, plastic \\
\hline & $100-150$ & $\begin{array}{l}7.5 \text { YR 5/8 } \\
7.5 \text { YR } 5 / 8\end{array}$ & Silt loam & Sub-angular blocky & Sticky, plastic \\
\hline \multirow{4}{*}{9} & $0-45$ & $\begin{array}{l}7.5 \text { YR 5/8 } \\
7.5 \text { YR } 6 / 8 \\
\end{array}$ & Sandy Loam & Sub-angular blocky & Slightly sticky, slightly plastic \\
\hline & $45-105$ & $\begin{array}{l}\text { 10YR 5/8 } \\
10 \text { YR 6/8 }\end{array}$ & Loam & Sub-angular blocky & Sticky, plastic \\
\hline & $105-130$ & $\begin{array}{l}\text { 10YR 5/8 } \\
10 \text { YR 6/8 }\end{array}$ & Sandy Loam & Sub-angular blocky & Slightly sticky, slightly plastic \\
\hline & $130-150$ & $\begin{array}{l}7.5 \text { YR } 6 / 8 \\
7.5 \text { YR } 5 / 8\end{array}$ & Loam & Sub-angular blocky & Sticky, plastic \\
\hline
\end{tabular}

Table 3. Physiographic units on the soil map

\begin{tabular}{|c|c|c|c|c|c|c|}
\hline Physiographic unit & Landforms & Mapping unit & Soil profile & $\begin{array}{l}\text { Profile elevation } \\
\text { (masl) }\end{array}$ & Area $\left(\mathrm{km}^{2}\right)$ & $\begin{array}{c}\text { Area } \\
(\%)\end{array}$ \\
\hline \multirow{10}{*}{ Flood plain } & High terraces & $\mathrm{T} 1$ & 9 & 12 & 232.21 & 12.05 \\
\hline & Moderately high terraces & $\mathrm{T} 2$ & 4 & 8 & 431.99 & 22.41 \\
\hline & Low Terraces & $\mathrm{T} 3$ & 1 & 0 & 417.8 & 21.68 \\
\hline & High Decantation Basin & D1 & 3 & 10 & 39.53 & 2.05 \\
\hline & Low Decantation Basin & D2 & 5 & 6 & 236.29 & 12.26 \\
\hline & High overflow Basin & OB1 & 6 & 7 & 244.461 & 12.68 \\
\hline & Low Overflow basin & $\mathrm{OB} 2$ & 7 & 5 & 206.45 & 10.71 \\
\hline & Levees & $\mathrm{L}$ & 8 & 9 & 103.82 & 5.39 \\
\hline & Swales & $S$ & 2 & 8 & 14.89 & 0.77 \\
\hline & Total & - & - & - & 1927.441 & 100.00 \\
\hline
\end{tabular}

${ }^{*}$ masl $=$ metres above sea level.

1: River terraces: these soils represent the late Pleistocene deltaic plain and occur at the edge of decantation basins (these are basins in which sedimentation, particularly of silt and clay, occur during floods). The soils are formed on terraces at various heights above the valley floor.

2: Basins: these are artificially enclosed areas of a river or harbour, designed so that water levels are unaffected by tides.

3: River levees: these are a type of dam that runs along the banks of rivers or canals. Levees reinforce the banks and help prevent flooding. By confining the flow, levees can also increase water velocity.

4: Swales: these are low tracts of land, usually consisting of moist and marshy lands. The term can refer to both natural and artificial landscape features. Artificial swales are often designed to manage water runoff, filter pollutants and increase rainwater infiltration. 


\section{Results and discussion}

\subsection{Physiographic map of the study area}

The satellite images show that the study area is a floodplain and includes high terraces (12.04\% of area), moderately high terraces $(22.41 \%)$, low terraces $(21.67 \%)$, high decantation basins (2.05\%), low decantation basins (12.26\%), high overflow basins (12.68\%), low overflow basins (10.71\%), river levees (5.38\%) and swales (0.77\%). The main physiographic soil units of the study area are reported in Table 3 and Figure 3.

\subsection{Heavy metal contamination}

$\mathrm{XRF}$ analyses of the soil samples identified the presence of $\mathrm{SiO}_{2}, \mathrm{Al}_{2} \mathrm{O}_{3}, \mathrm{P}_{2} \mathrm{O}_{5}, \mathrm{~K} 2 \mathrm{O}, \mathrm{CaO}, \mathrm{MgO}, \mathrm{Na}_{2} \mathrm{O}$ and $\mathrm{Fe}_{2} \mathrm{O}_{3}$ (major) and $\mathrm{Cr}, \mathrm{Cu}, \mathrm{Zn}, \mathrm{Ni}, \mathrm{Br}, \mathrm{Rb}, \mathrm{Sr}, \mathrm{Y}, \mathrm{Zr}, \mathrm{Nb}, \mathrm{Sn}, \mathrm{Te}, \mathrm{Ba}$, $\mathrm{Eu}, \mathrm{Yb}, \mathrm{Re}, \mathrm{Ga}$, Ir, Mo, As and $\mathrm{Pb}$ (minor). Concentrations of the heavy metals $\mathrm{Cr}, \mathrm{Cu}, \mathrm{Ni}, \mathrm{V}$ and $\mathrm{Zn}$ for each profile are reported in Table 4. For the metals Te, Mo, As and $\mathrm{Pb}$, results are not reported, because their concentrations were below detection limits. Spatial interpolation maps (Figs 4-7) of heavy metal concentrations were prepared using the IDW function (inverse distance weighted) interpolation method in Arc GIS 10.1.

\section{Vanadium}

The concentrations and the interpolation map for $\mathrm{V}$ in the soil samples are given in Table 4 and Figure 4 . V concentrations ranged from $194.0-744.4 \mathrm{mg} / \mathrm{kg}$ with a weighted mean ranging from $206.79-450.58 \mathrm{mg} / \mathrm{kg}$ (Table 5). The highest measured concentration of $\mathrm{V}$ was in the upper horizon of Profile 2, which represents a swales unit and is located $270 \mathrm{~m}$ north of Mansuriyyat Al-Farastaq village, $\sim 6.5 \mathrm{~km}$ south-west from the centre of the town of $\mathrm{Kfr}$ Elzayat (population in 2015 was 448,965). The Igeo Index showed that all soil samples were in the uncontaminated/ moderately contaminated categories, except for first horizon of Profile 2 in the swales mapping unit, which is classified as moderately/strongly contaminated (Table 6). The high deposition of $\mathrm{V}$ might be caused by the numerous local factories. $\mathrm{V}$ concentrations are higher than the permissible limits (90 mg/kg), recommended by Bowen (1979) in all soil profile horizons (Table 5). The spatial interpolation shows an increasing trend from north-east to south-west. The highest weighted mean (weighting concentration by representative area) $(450.58 \mathrm{mg} / \mathrm{kg})$ was found in $0.77 \%$ of the study area. From the interpolation map of $\mathrm{V}$ in the study area (Fig. 4) we can conclude that the order of concentration ascending in the mapping units is: low decantation basin (D2), high overflow basin (OB1), low overflow basin (OB2), moderately high terraces (T2), high decantation basin (D1), levees (L), high terraces (T1), low terraces (T3) and swales (S).

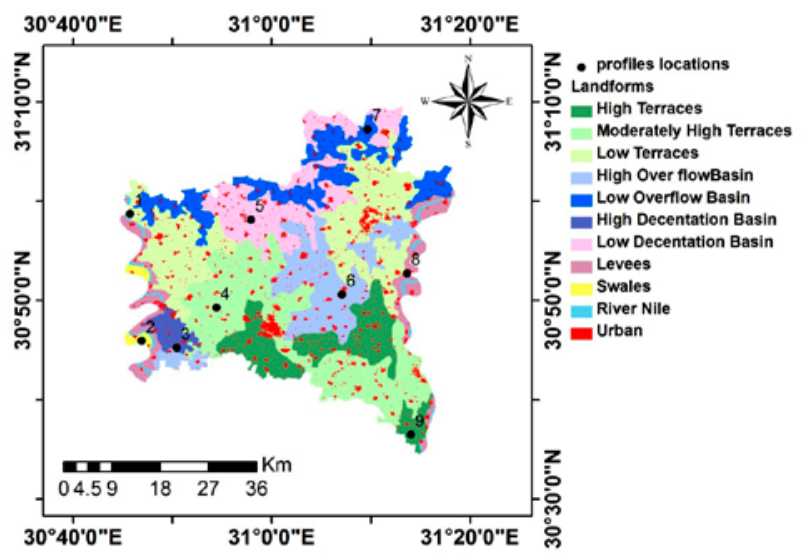

Fig. 3. The main landforms of the study area and profile locations

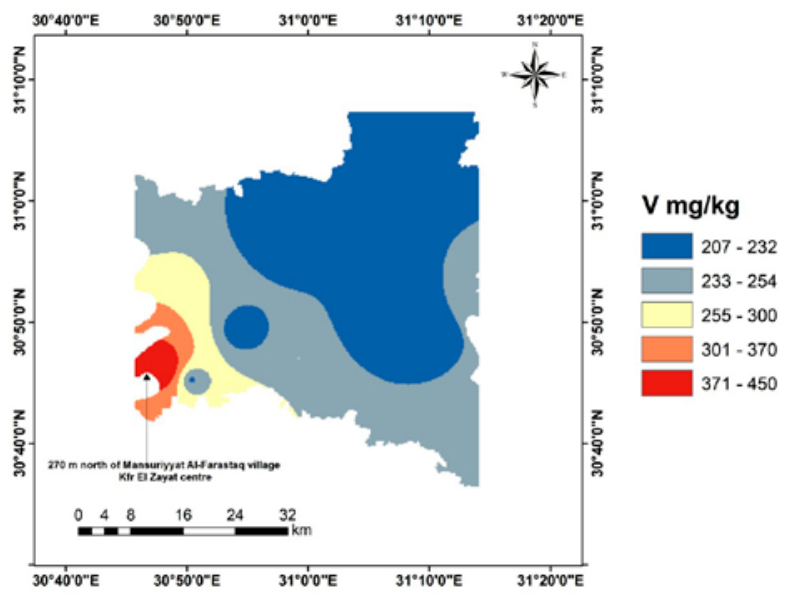

Fig. 4. Spatial interpolation of the weighted mean of vanadium

\section{Chromium}

Anthropogenic sources of $\mathrm{Cr}$ include alloys, chrome plating, pigments, chemical catalysts, dyes, tanning, wood impregnation and refractory bricks (Reimann, de Caritat 1998). The highest concentration of $\mathrm{Cr}(519 \mathrm{mg} / \mathrm{kg})$ was in the top-soil of Profile 2, which may be due to the many local factories. The lowest $(140.3 \mathrm{mg} / \mathrm{kg})$ was in the topsoil of Profile 6, which represents a high over-flow basin (Table 4 ). The mean weight of $\mathrm{Cr}$ concentrations ranged from $152.84-314.73 \mathrm{mg} / \mathrm{kg}$ (Table 5). All concentrations exceeded the recommended values given by Bowen (1979) and, according to the Igeo Index, most soil samples are in the uncontaminated/moderately contaminated category (Table 6). Cr concentrations increased from east to west and south of the study area (Fig. 5). The highest Cr concentrations tended to be in the swales unit and the lowest in the high overflow basin unit. 


\section{Nickel}

Baghdady, Sippola (1984) reported that the mean total $\mathrm{Ni}$ content in Egyptian alluvial soils is $64.4 \mathrm{mg} / \mathrm{kg}$, ranging from $20-74 \mathrm{mg} / \mathrm{kg}$, while the mean $\mathrm{NH}_{4} \mathrm{OAC}-\mathrm{EDTA}$ extractable $\mathrm{Ni}$ is $1.9 \mathrm{mg} / \mathrm{kg}$, ranging from $1.0-2.2 \mathrm{mg} /$ $\mathrm{kg}$. However, in this study, $\mathrm{Ni}$ concentrations ranged from $60.60-267.30 \mathrm{mg} / \mathrm{kg}$ (Table 4 ), with mean weight ranging from $69.60-148.39 \mathrm{mg} / \mathrm{kg}$ (Table 5). Ni concentrations were higher in alluvial soils than previous studies and exceeded the permissible limit $(50 \mathrm{mg} / \mathrm{kg}$ ) (Bowen 1979). According to the Igeo Index, all samples are in the uncontaminated and moderately contaminated categories (Table 6). Table 4 reports $\mathrm{Ni}$ concentrations in soil profiles and Figure 6 shows the spatial trends, which increased from north to south and west. The highest concentrations were in swales, which occupy $14.89 \mathrm{~km}^{2}$ of the study area. The interpolation of $\mathrm{Ni}$ shows high spatial variability, with the lowest values in the high decantation basin units.

\section{Copper}

Table 4 and Figure 7 report $\mathrm{Cu}$ concentrations and the spatial interpolation of weighted mean $\mathrm{Cu}$ concentrations, respectively. $\mathrm{Cu}$ contents in horizons ranged from

Table 4. XRF analysis of soils collected from the study area

\begin{tabular}{|c|c|c|c|c|c|c|c|}
\hline \multirow{2}{*}{ Profile no } & \multirow{2}{*}{ Mapping unit } & \multirow{2}{*}{ Depth $(\mathrm{cm})$} & \multicolumn{5}{|c|}{ Metal concentrations (mg/kg) } \\
\hline & & & $\mathrm{V}$ & $\mathrm{Cr}$ & $\mathrm{Ni}$ & $\mathrm{Cu}$ & $\mathrm{Zn}$ \\
\hline \multirow{4}{*}{1} & \multirow{4}{*}{$\mathrm{T} 3$} & $0-50$ & 227.1 & 179.7 & 68.30 & 78.60 & 94.30 \\
\hline & & $50-85$ & 265.9 & 158.1 & 77.80 & 60.90 & 85.40 \\
\hline & & $85-120$ & 250.4 & 167.3 & 73.50 & 81.40 & 93.30 \\
\hline & & $120-150$ & 221.8 & 163.3 & 61.60 & 60.10 & 80.80 \\
\hline \multirow{3}{*}{2} & \multirow{3}{*}{$\mathrm{S}$} & $0-45$ & 744.4 & 519.0 & 267.30 & 288.90 & 377.60 \\
\hline & & $45-85$ & 244.9 & 161.4 & 63.50 & 50.90 & 75.50 \\
\hline & & $85-110$ & 250.8 & 192.4 & 70.20 & 71.40 & 86.80 \\
\hline \multirow{3}{*}{3} & \multirow{3}{*}{ D1 } & $0-75$ & 221.0 & 170.7 & 63.80 & 94.50 & 90.20 \\
\hline & & $75-100$ & 241.4 & 179.6 & 63.00 & 73.00 & 86.90 \\
\hline & & $100-150$ & 238.9 & 166.6 & 81.60 & 76.60 & 85.00 \\
\hline \multirow{4}{*}{4} & \multirow{4}{*}{$\mathrm{T} 2$} & $0-60$ & 203.1 & 159.2 & 72.30 & 118.70 & 308.00 \\
\hline & & $60-100$ & 258.3 & 166.3 & 70.90 & 0.00 & 88.70 \\
\hline & & $100-120$ & 222.8 & 166.2 & 65.50 & 75.20 & 84.90 \\
\hline & & $120-150$ & 206.1 & 179.8 & 70.70 & 72.30 & 91.60 \\
\hline \multirow{4}{*}{5} & \multirow{4}{*}{ D2 } & $0-45$ & 194.0 & 149.1 & 74.40 & 95.20 & 103.10 \\
\hline & & $45-65$ & 197.5 & 159.6 & 69.20 & 93.30 & 98.40 \\
\hline & & $65-110$ & 225.3 & 143.0 & 73.20 & 95.50 & 95.00 \\
\hline & & $110-150$ & 205.0 & 150.5 & 72.20 & 94.60 & 98.80 \\
\hline \multirow{4}{*}{6} & \multirow{4}{*}{ OB1 } & $0-35$ & 210.1 & 140.3 & 60.60 & 131.80 & 124.50 \\
\hline & & $35-65$ & 216.0 & 152.7 & 76.70 & 76.40 & 109.40 \\
\hline & & $65-100$ & 220.9 & 164.3 & 84.50 & 97.50 & 103.20 \\
\hline & & $100-150$ & 219.5 & 153.7 & 85.00 & 0.00 & 100.60 \\
\hline \multirow{3}{*}{7} & \multirow{3}{*}{ OB2 } & $0-55$ & 228.2 & 180.8 & 76.50 & 93.50 & 94.70 \\
\hline & & $55-110$ & 230.3 & 170.7 & 73.30 & 89.10 & 84.70 \\
\hline & & $110-150$ & 196.5 & 168.7 & 64.50 & 74.10 & 84.30 \\
\hline \multirow{4}{*}{8} & \multirow{4}{*}{$\mathrm{L}$} & $0-30$ & 218.7 & 164.1 & 68.90 & 0.00 & 93.20 \\
\hline & & $30-60$ & 241.3 & 151.3 & 73.90 & 0.00 & 97.10 \\
\hline & & $60-100$ & 247.3 & 155.4 & 82.10 & 0.00 & 89.50 \\
\hline & & $100-150$ & 231.9 & 154.9 & 75.40 & 85.80 & 93.80 \\
\hline \multirow{4}{*}{9} & \multirow{4}{*}{$\mathrm{T} 1$} & $0-45$ & 250.7 & 156.8 & 78.20 & 0.00 & 112.10 \\
\hline & & $45-105$ & 232.8 & 158.1 & 80.90 & 74.30 & 103.30 \\
\hline & & $105-130$ & 223.7 & 168.8 & 76.40 & 74.50 & 89.50 \\
\hline & & $130-150$ & 231.1 & 168.4 & 69.70 & 74.10 & 94.00 \\
\hline
\end{tabular}


Table 5. Heavy metal concentrations in soil samples and concentration limits recommended by Bowen (1979)

\begin{tabular}{ccccccc}
\hline \multirow{2}{*}{$\begin{array}{c}\text { Profile } \\
\text { No }\end{array}$} & $\begin{array}{c}\text { Map- } \\
\text { ping } \\
\text { unit }\end{array}$ & \multicolumn{5}{c}{ Mean weight of metals concentrations } \\
\cline { 3 - 7 }$(\mathrm{mg} / \mathrm{kg})$
\end{tabular}

$0-288.9 \mathrm{mg} / \mathrm{kg}$ and mean weight ranged from $28.90-$ $152.92 \mathrm{mg} / \mathrm{kg}$ (Table 5). All concentrations exceeded the permissible limit of $25 \mathrm{mg} / \mathrm{kg}$ (Bowen 1979), except for the second horizon of Profile 4 and the first, second and the third horizons of Profile 8 (Table 4). In addition, in Profile 9 the deepest horizon exceeded the limit, whereas concentrations in the upper layer were 0 . This is probably due to percolation and illuviation of $\mathrm{Cu}$ associated with irrigation water. These profiles represent moderately high terraces, levees and high terraces, respectively. The Igeo Index showed that soil samples were in three contamination categories (uncontaminated/ moderately contaminated, moderately contaminated and moderately/strongly contaminated) (Table 6). Two important sources of $\mathrm{Cu}$ in the Nile Delta are: (i) applications of $\mathrm{Cu}$-based liquid fungicides, and (ii) use of $\mathrm{CuSO}_{4}$ as an algicide in treating and controlling problematic macro-algal blooms in the Nile, especially during summer (Abdel-Moati, El-Sammak 1997). The lowest $\mathrm{Cu}$ concentrations were in the river levees units and the highest values were in the swale units.

\section{Zinc}

Zn concentrations slightly exceed the permissible concentration limit of $90 \mathrm{mg} / \mathrm{kg}$ (Bowen 1979) (Table 5). Exceptions include the upper layers of Profiles 2 and 4, where concentrations greatly exceeded permissible limits (377.6 and $308.0 \mathrm{mg} / \mathrm{kg}$, respectively). The highest concentrations were in the upper horizon, but in Profile 8 the highest concentration was in the subsurface (Table 4). This could be caused by infiltration of irrigation water through the profile. The mean weight of $\mathrm{Zn}$ ranged between 88.26$201.65 \mathrm{mg} / \mathrm{kg}$. According to the Igeo Index, the Zn concentrations of all soil samples fell into the uncontaminated

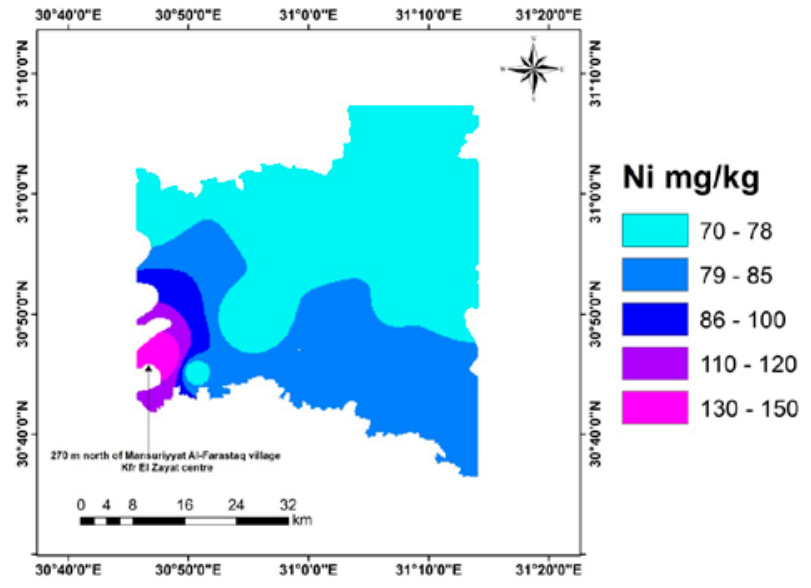

Fig. 6. Spatial interpolation of the weighted mean of nickel



Fig. 7. Spatial interpolation of the weighted mean of copper



Fig. 8. Spatial interpolation of the weighted mean of zinc

category, except for the first horizons of Profiles 2 and 4, which were moderately contaminated (Table 6 ). The spatial interpolation of $\mathrm{Zn}$ is presented in Figure 8. The highest concentration was in the south-west of the study area, which is located $270 \mathrm{~m}$ north of Mansuriyyat Al-Farastaq 
village. This could be due to atmospheric deposition, originating from local industrial plants. The highest $\mathrm{Zn}$ concentrations were in the swales top-soil and moderately high terrace units.

\subsection{Major soil oxides}

Soil samples were analysed for heavy metals and major oxides (Table 7). Results for $\mathrm{SiO}_{2}, \mathrm{Al}_{2} \mathrm{O}_{3}, \mathrm{P}_{2} \mathrm{O}_{5}, \mathrm{~K}_{2} \mathrm{O}$, $\mathrm{CaO}, \mathrm{MgO}, \mathrm{Na}_{2} \mathrm{O}$ and $\mathrm{Fe}_{2} \mathrm{O}_{3}$ were compared with average concentrations of major oxides in soil (Bohn et al. 2001)
(Table 5). $\mathrm{SiO}_{2}$ concentrations varied from $51.40-56.55 \%$ and were all less than the representative average value of $72.64 \%$ (Bohn et al. 2001). $\mathrm{Al}_{2} \mathrm{O}_{3}$ concentrations varied from $16.28-24.42 \%$ and the mean concentration of profiles ranged from $18.81-22.9 \%$. $\mathrm{Al}_{2} \mathrm{O}_{3}$ concentrations in all samples exceeded the representative mean value of $13.22 \% . \mathrm{K}_{2} \mathrm{O}$ concentrations ranged from $1.05-1.62 \%$ with weighted mean values ranging from $1.14-1.35 \%$, near the $1.2 \%$ representative mean. $\mathrm{CaO}$ concentrations ranged between $2.58-6.69 \%$ and the mean weighted value

Table 6. Igeo Index concentrations and associated contamination levels

\begin{tabular}{|c|c|c|c|c|c|c|c|c|c|c|c|}
\hline $\begin{array}{c}\text { Profile } \\
\text { no }\end{array}$ & $\begin{array}{l}\text { Depth, } \\
\mathrm{cm}\end{array}$ & $\mathrm{V}$ & C level & $\mathrm{Cr}$ & C Level & $\mathrm{Ni}$ & C Level & $\mathrm{Cu}$ & C level & $\mathrm{Zn}$ & $C$ level \\
\hline \multirow{4}{*}{1} & $0-50$ & 0.75 & UN/M & 0.77 & $\mathrm{UN} / \mathrm{M}$ & ND & UN & 1.06 & $\mathrm{M}$ & $\mathrm{ND}$ & UN \\
\hline & $50-85$ & 0.97 & $\mathrm{UN} / \mathrm{M}$ & 0.59 & $\mathrm{UN} / \mathrm{M}$ & 0.05 & UN/M & 0.69 & UN/M & ND & UN \\
\hline & $85-120$ & 0.89 & $\mathrm{UN} / \mathrm{M}$ & 0.67 & $\mathrm{UN} / \mathrm{M}$ & ND & UN & 1.11 & $M$ & $\mathrm{ND}$ & UN \\
\hline & $120-150$ & 0.71 & $\mathrm{UN} / \mathrm{M}$ & 0.63 & $\mathrm{UN} / \mathrm{M}$ & ND & UN & 0.68 & UN/M & ND & UN \\
\hline \multirow{3}{*}{2} & $0-45$ & 2.46 & $\mathrm{M} / \mathrm{S}$ & 2.30 & $\mathrm{M} / \mathrm{S}$ & 1.83 & $\mathrm{M}$ & 2.94 & $\mathrm{M} / \mathrm{S}$ & 1.48 & $\mathrm{M}$ \\
\hline & $45-85$ & 0.85 & $\mathrm{UN} / \mathrm{M}$ & 0.62 & $\mathrm{UN} / \mathrm{M}$ & ND & UN & 0.44 & $\mathrm{UN} / \mathrm{M}$ & $\mathrm{ND}$ & UN \\
\hline & $85-110$ & 0.89 & $\mathrm{UN} / \mathrm{M}$ & 0.87 & $\mathrm{UN} / \mathrm{M}$ & ND & UN & 0.92 & $\mathrm{UN} / \mathrm{M}$ & ND & UN \\
\hline \multirow{3}{*}{3} & $0-75$ & 0.71 & UN/M & 0.70 & $\mathrm{UN} / \mathrm{M}$ & ND & UN & 1.33 & $\mathrm{M}$ & $\mathrm{ND}$ & UN \\
\hline & $75-100$ & 0.83 & $\mathrm{UN} / \mathrm{M}$ & 0.77 & $\mathrm{UN} / \mathrm{M}$ & ND & UN & 0.96 & UN/M & ND & UN \\
\hline & $100-150$ & 0.82 & $\mathrm{UN} / \mathrm{M}$ & 0.66 & $\mathrm{UN} / \mathrm{M}$ & 0.12 & UN/M & 1.03 & M & ND & UN \\
\hline \multirow{4}{*}{4} & $0-60$ & 0.58 & $\mathrm{UN} / \mathrm{M}$ & 0.60 & $\mathrm{UN} / \mathrm{M}$ & ND & UN & 1.66 & $M$ & 1.18 & $M$ \\
\hline & $60-100$ & 0.93 & UN/M & 0.66 & $\mathrm{UN} / \mathrm{M}$ & ND & UN & $\mathrm{ND}$ & - & $\mathrm{ND}$ & UN \\
\hline & $100-120$ & 0.72 & UN/M & 0.66 & $\mathrm{UN} / \mathrm{M}$ & ND & UN & 1.00 & $\mathrm{M}$ & ND & UN \\
\hline & $120-150$ & 0.61 & $\mathrm{UN} / \mathrm{M}$ & 0.77 & $\mathrm{UN} / \mathrm{M}$ & ND & UN & 0.94 & $\mathrm{UN} / \mathrm{M}$ & $\mathrm{ND}$ & UN \\
\hline \multirow{4}{*}{5} & $0-45$ & 0.52 & $\mathrm{UN} / \mathrm{M}$ & 0.50 & $\mathrm{UN} / \mathrm{M}$ & ND & $\mathrm{UN} / \mathrm{M}$ & 1.34 & $M$ & $\mathrm{ND}$ & UN \\
\hline & $45-65$ & 0.54 & $\mathrm{UN} / \mathrm{M}$ & 0.60 & $\mathrm{UN} / \mathrm{M}$ & ND & UN & 1.31 & $M$ & $\mathrm{ND}$ & UN \\
\hline & $65-110$ & 0.73 & $\mathrm{UN} / \mathrm{M}$ & 0.44 & $\mathrm{UN} / \mathrm{M}$ & ND & UN & 1.34 & $\mathrm{M}$ & ND & UN \\
\hline & $110-150$ & 0.60 & $\mathrm{UN} / \mathrm{M}$ & 0.51 & $\mathrm{UN} / \mathrm{M}$ & ND & UN & 1.33 & M & ND & UN \\
\hline \multirow{4}{*}{6} & $0-35$ & 0.63 & $\mathrm{UN} / \mathrm{M}$ & 0.41 & $\mathrm{UN} / \mathrm{M}$ & ND & UN & 1.81 & $M$ & ND & UN \\
\hline & $35-65$ & 0.67 & $\mathrm{UN} / \mathrm{M}$ & 0.54 & $\mathrm{UN} / \mathrm{M}$ & 0.03 & UN/M & 1.02 & $M$ & ND & UN \\
\hline & $65-100$ & 0.71 & $\mathrm{UN} / \mathrm{M}$ & 0.64 & $\mathrm{UN} / \mathrm{M}$ & 0.17 & UN/M & 1.37 & $M$ & $\mathrm{ND}$ & UN \\
\hline & $100-150$ & 0.70 & $\mathrm{UN} / \mathrm{M}$ & 0.54 & $\mathrm{UN} / \mathrm{M}$ & 0.18 & UN/M & ND & - & ND & UN \\
\hline \multirow{3}{*}{7} & $0-55$ & 0.75 & UN/M & 0.78 & $\mathrm{UN} / \mathrm{M}$ & 0.02 & UN/M & 1.31 & M & ND & UN \\
\hline & $55-110$ & 0.77 & UN/M & 0.70 & $\mathrm{UN} / \mathrm{M}$ & ND & UN & 1.24 & $\mathrm{M}$ & ND & UN \\
\hline & $110-150$ & 0.54 & $\mathrm{UN} / \mathrm{M}$ & 0.68 & $\mathrm{UN} / \mathrm{M}$ & ND & UN & 0.98 & $\mathrm{UN} / \mathrm{M}$ & $\mathrm{ND}$ & UN \\
\hline \multirow{4}{*}{8} & $0-30$ & 0.69 & UN/M & 0.64 & $\mathrm{UN} / \mathrm{M}$ & ND & UN & $\mathrm{ND}$ & - & $\mathrm{ND}$ & UN \\
\hline & $30-60$ & 0.83 & $\mathrm{UN} / \mathrm{M}$ & 0.52 & $\mathrm{UN} / \mathrm{M}$ & ND & UN & $\mathrm{ND}$ & - & ND & UN \\
\hline & $60-100$ & 0.87 & $\mathrm{UN} / \mathrm{M}$ & 0.56 & $\mathrm{UN} / \mathrm{M}$ & 0.13 & $\mathrm{UN} / \mathrm{M}$ & $\mathrm{ND}$ & - & ND & UN \\
\hline & $100-150$ & 0.78 & $\mathrm{UN} / \mathrm{M}$ & 0.56 & $\mathrm{UN} / \mathrm{M}$ & 0.007 & $\mathrm{UN} / \mathrm{M}$ & 1.19 & $M$ & ND & UN \\
\hline \multirow{4}{*}{9} & $0-45$ & 0.89 & $\mathrm{UN} / \mathrm{M}$ & 0.57 & $\mathrm{UN} / \mathrm{M}$ & 0.06 & $\mathrm{UN} / \mathrm{M}$ & ND & - & ND & UN \\
\hline & 45-105 & 0.78 & $\mathrm{UN} / \mathrm{M}$ & 0.59 & $\mathrm{UN} / \mathrm{M}$ & 0.1 & $\mathrm{UN} / \mathrm{M}$ & 0.98 & $\mathrm{UN} / \mathrm{M}$ & ND & UN \\
\hline & $105-130$ & 0.72 & $\mathrm{UN} / \mathrm{M}$ & 0.68 & $\mathrm{UN} / \mathrm{M}$ & 0.02 & UN/M & 0.99 & UN/M & ND & UN \\
\hline & $130-150$ & 0.77 & UN/M & 0.68 & $\mathrm{UN} / \mathrm{M}$ & ND & UN & 0.98 & UN/M & $\mathrm{ND}$ & UN \\
\hline
\end{tabular}

C Level = Contamination level; $\mathrm{UN}=$ Uncontaminated; $\mathrm{UN} / \mathrm{M}=$ Uncontaminated/moderately contaminated; $\mathrm{M}=$ Moderately contaminated; $\mathrm{M} / \mathrm{S}=$ Moderately/strongly contaminated; ND $=$ Not detected 
ranged between $3.70-5.95 \%$. $\mathrm{CaO}$ and $\mathrm{Na}_{2} \mathrm{O}$ concentrations exceeded the representative means of $1.44 \%$ and $0.99 \%$, respectively. $\mathrm{Fe}_{2} \mathrm{O}_{3}$ concentration ranged between $9.73-12.23 \%$, whereas the representative mean is $5.77 \%$. $\mathrm{P}_{2} \mathrm{O}_{5}$ concentrations ranged from $0.15-0.49 \%$. The weighted mean concentrations of $\mathrm{P}_{2} \mathrm{O}_{5}$ samples exceed the $0.18 \%$ representative mean (Table 8). Thus, these deltaic soils are predominantly siliceous, with slight enrichment of the alumina component.

\subsection{Relationships between trace and major elements}

$\mathrm{V}, \mathrm{Cr}, \mathrm{Ni}, \mathrm{Cu}$ and $\mathrm{Zn}$ concentrations are significantly correlated (Table 9). There are no significant correlations between major elements and heavy metal concentrations, except for $\mathrm{V}, \mathrm{Ni}$ and $\mathrm{Zn}$. V and Ni have significant positive medium and strong correlations with Fe, respectively. This may indicate the sorption of these elements by Fe hydroxides. $\mathrm{Ni}$ has a strong positive association with $\mathrm{Al}$, whereas a strong significant association was found between $\mathrm{Zn}$ and

Table 7. Summary of major oxide concentrations in soil samples of the study area

\begin{tabular}{|c|c|c|c|c|c|c|c|c|c|c|}
\hline \multirow{2}{*}{ Profile No. } & \multirow{2}{*}{$\begin{array}{c}\text { Mapping } \\
\text { unit }\end{array}$} & \multirow{2}{*}{ Depth, cm } & \multicolumn{8}{|c|}{ Major oxide concentrations (\%) } \\
\hline & & & $\mathrm{SiO}_{2}$ & $\mathrm{Al}_{2} \mathrm{O}_{3}$ & $\mathrm{P}_{2} \mathrm{O}_{5}$ & $\mathrm{~K}_{2} \mathrm{O}$ & $\mathrm{CaO}$ & $\mathrm{MgO}$ & $\mathrm{Na}_{2} \mathrm{O}$ & $\mathrm{Fe}_{2} \mathrm{O}_{3}$ \\
\hline \multirow{4}{*}{1} & \multirow{4}{*}{$\mathrm{T} 3$} & $0-50$ & 52.67 & 20.10 & 0.31 & 1.29 & 3.66 & 4.18 & 1.44 & 10.93 \\
\hline & & $50-85$ & 56.46 & 23.92 & 0.25 & 1.29 & 3.18 & 4.53 & 1.44 & 12.03 \\
\hline & & $85-120$ & 55.12 & 21.48 & 0.23 & 1.16 & 3.88 & 4.43 & 1.77 & 11.54 \\
\hline & & $120-150$ & 54.42 & 19.28 & 0.21 & 1.19 & 4.17 & 3.98 & 2.02 & 10.38 \\
\hline \multirow{3}{*}{2} & \multirow{3}{*}{$S$} & $0-45$ & ND & ND & ND & $\mathrm{ND}$ & $\mathrm{ND}$ & ND & ND & ND \\
\hline & & $45-85$ & 52.26 & 18.57 & 0.24 & 1.21 & 4.98 & 4.66 & 1.55 & 11.16 \\
\hline & & $85-110$ & 55.35 & 21.50 & 0.20 & 1.10 & 4.50 & 4.62 & 1.89 & 11.28 \\
\hline \multirow{3}{*}{3} & \multirow{3}{*}{ D1 } & $0-75$ & 54.33 & 20.74 & 0.39 & 1.45 & 4.53 & 4.83 & 1.48 & 10.51 \\
\hline & & $75-100$ & 52.83 & 18.36 & 0.20 & 1.10 & 5.03 & 4.30 & 1.72 & 11.20 \\
\hline & & $100-150$ & 54.03 & 20.96 & 0.18 & 1.08 & 4.63 & 4.59 & 1.66 & 11.03 \\
\hline \multirow{4}{*}{4} & \multirow{4}{*}{$\mathrm{T} 2$} & $0-60$ & 55.87 & 19.11 & 0.43 & 1.60 & 3.70 & 5.11 & 1.49 & 10.61 \\
\hline & & $60-100$ & 56.55 & 21.37 & 0.20 & 1.31 & 4.26 & 5.26 & 1.47 & 10.77 \\
\hline & & $100-120$ & 53.60 & 18.24 & ND & 1.13 & 6.69 & 4.96 & 1.70 & 10.78 \\
\hline & & $120-150$ & 52.15 & 16.48 & 0.20 & 1.07 & 6.34 & 4.55 & 1.84 & 10.28 \\
\hline \multirow{4}{*}{5} & \multirow{4}{*}{ D2 } & $0-45$ & 52.70 & 18.80 & 0.46 & 1.30 & 5.36 & 5.16 & 1.42 & 10.54 \\
\hline & & $45-65$ & 54.20 & 19.19 & 0.20 & 1.24 & 4.38 & 5.43 & 1.43 & 10.96 \\
\hline & & $65-110$ & 54.88 & 19.60 & 0.17 & 1.20 & 3.56 & 5.57 & 1.50 & 11.03 \\
\hline & & $110-150$ & 53.93 & 19.20 & 0.28 & 1.25 & 4.43 & 5.39 & 1.45 & 10.84 \\
\hline \multirow{4}{*}{6} & \multirow{4}{*}{ OB1 } & $0-35$ & 54.64 & 19.19 & 0.49 & 1.62 & 5.22 & 4.99 & 1.48 & 10.82 \\
\hline & & $35-65$ & 55.46 & 22.14 & 0.29 & 1.35 & 4.03 & 4.99 & 1.39 & 11.44 \\
\hline & & $65-100$ & 55.71 & 23.59 & 0.20 & 1.25 & 3.47 & 5.00 & 1.36 & 11.74 \\
\hline & & $100-150$ & 56.04 & 23.64 & 0.19 & 1.18 & 3.40 & 4.99 & 1.33 & 11.75 \\
\hline \multirow{3}{*}{7} & \multirow{3}{*}{ OB2 } & $0-55$ & 56.43 & 19.43 & 0.24 & 1.39 & 4.74 & 5.88 & 1.60 & 10.72 \\
\hline & & $55-110$ & 55.29 & 19.4 & 0.15 & 1.22 & 3.06 & 4.99 & 2.44 & 10.59 \\
\hline & & $110-150$ & 53.4 & 17.14 & 0.17 & 1.28 & 4.31 & 4.62 & 2.80 & 9.72 \\
\hline \multirow{4}{*}{8} & \multirow{4}{*}{$\mathrm{L}$} & $0-30$ & 52.38 & 19.40 & 0.32 & 1.22 & 4.23 & 4.35 & 1.59 & 10.38 \\
\hline & & $30-60$ & 54.42 & 19.47 & 0.28 & 1.21 & 4.35 & 4.90 & 1.62 & 11.11 \\
\hline & & $60-100$ & 55.01 & 23.20 & 0.21 & 1.09 & 3.45 & 4.80 & 1.50 & 11.67 \\
\hline & & $100-150$ & 56.06 & 24.42 & 0.17 & 1.09 & 2.58 & 4.79 & 1.40 & 12.23 \\
\hline \multirow{4}{*}{9} & \multirow{4}{*}{$\mathrm{T} 1$} & $0-45$ & 51.40 & 17.93 & 0.31 & 1.47 & 4.67 & 4.93 & 1.52 & 11.06 \\
\hline & & 45-105 & 52.32 & 19.01 & 0.20 & 1.14 & 4.32 & 4.78 & 1.64 & 11.43 \\
\hline & & $105-130$ & 52.36 & 21.47 & 0.16 & 1.05 & 3.12 & 4.52 & 1.70 & 11.73 \\
\hline & & $130-150$ & 52.09 & 21.08 & 0.15 & 1.05 & 3.17 & 4.44 & 1.71 & 11.68 \\
\hline
\end{tabular}

\footnotetext{
${ }^{\star} \mathrm{ND}=$ Not detected.
} 
$\mathrm{K}_{2} \mathrm{O}$ and a medium correlation with $\mathrm{P}_{2} \mathrm{O}_{5}$. Such associations indicate strong affinity for these elements for $\mathrm{Fe}, \mathrm{Al}$ and $\mathrm{K}$ oxides. $\mathrm{Al}_{2} \mathrm{O}_{3}$ and $\mathrm{Fe}_{2} \mathrm{O}_{3}$ display a strong positive significant correlation. In addition, $\mathrm{P}_{2} \mathrm{O}_{5}$ is significantly correlated with $\mathrm{K}_{2} \mathrm{O}$. There are strong significant negative correlations between $\mathrm{Al}_{2} \mathrm{O}_{3}$ and $\mathrm{CaO}$, between $\mathrm{CaO}$ and $\mathrm{Fe}_{2} \mathrm{O}_{3}$ and a medium significant negative correlation between $\mathrm{Na}_{2} \mathrm{O}$ and $\mathrm{Fe}_{2} \mathrm{O}_{3}$.

\section{Conclusions}

This study shows that concentrations of $\mathrm{V}, \mathrm{Ni}$ and $\mathrm{Cr}$ exceeded recommended limits in the soils of the Middle Nile Delta. $\mathrm{Cu}$ concentrations were very variable. $\mathrm{Zn}$ concentrations slightly exceed the recommended limit. V, Cr, $\mathrm{Ni}, \mathrm{Cu}$ and $\mathrm{Zn}$ concentrations are significantly correlated. There are no significant correlations between major elements and heavy metal concentrations, except for $\mathrm{V}, \mathrm{Ni}$ and $\mathrm{Zn}$. $\mathrm{V}$ and $\mathrm{Ni}$ have significant positive medium and strong correlations with $\mathrm{Fe}$, respectively. The Igeo Index of $\mathrm{V}$ showed that all soil samples were in the uncontaminated/moderately contaminated categories, except for the first horizon of Profile 2, which is classified as moderately/strongly contaminated, while the Igeo Index for $\mathrm{Cr}$ showed most soil samples are in the uncontaminated/ moderately contaminated category. The Igeo Index for $\mathrm{Ni}$ reveals that all samples are in the uncontaminated and moderately contaminated categories. For $\mathrm{Cu}$, soil samples were in three contamination categories (uncontaminated/ moderately contaminated, moderately contaminated and moderately/strongly contaminated). All $\mathrm{Zn}$ concentrations were in the uncontaminated category, except for the first horizons of Profiles 2 and 4, which were moderately contaminated. The highest heavy metal concentrations dominate the south-west of El-Gharbia Governorate and is mainly attributed to human activities, especially pollution

Table 8. Mean weight of major oxide concentrations in soil samples and representative average limits (Bohn et al. 2001)

\begin{tabular}{ccccccccccc}
\hline \multirow{2}{*}{ Profile No. } & \multirow{2}{*}{$\begin{array}{c}\text { Mapping } \\
\text { unit }\end{array}$} & $\mathrm{SiO}_{2}$ & $\mathrm{Al}_{2} \mathrm{O}_{3}$ & $\mathrm{P}_{2} \mathrm{O}_{5}$ & $\mathrm{~K}_{2} \mathrm{O}$ & $\mathrm{CaO}$ & $\mathrm{MgO}$ & $\mathrm{Na}_{2} \mathrm{O}^{2} \mathrm{Fe}_{2} \mathrm{O}_{3}$ \\
\hline & $\mathrm{T} 3$ & 54.47 & 21.14 & 0.25 & 1.23 & 3.70 & 4.27 & 1.63 & 11.21 \\
\hline 1 & $\mathrm{~S}$ & $\mathrm{ND}$ & $\mathrm{ND}$ & $\mathrm{ND}$ & $\mathrm{ND}$ & $\mathrm{ND}$ & $\mathrm{ND}$ & $\mathrm{ND}$ & $\mathrm{ND}$ \\
\hline 2 & $\mathrm{D} 1$ & 53.97 & 20.40 & 0.28 & 1.27 & 4.64 & 4.66 & 1.58 & 10.79 \\
\hline 3 & $\mathrm{~T} 2$ & 55.06 & 19.07 & $\mathrm{ND}$ & 1.35 & 4.77 & 5.01 & 1.57 & 10.60 \\
\hline 4 & $\mathrm{D} 2$ & 53.88 & 19.19 & 0.28 & 1.24 & 4.44 & 5.38 & 1.45 & 10.82 \\
\hline 5 & $\mathrm{OB} 1$ & 55.51 & 22.29 & 0.28 & 1.33 & 5.95 & 4.99 & 1.38 & 11.47 \\
\hline 6 & $\mathrm{OB} 2$ & 55.20 & 18.81 & 0.18 & 1.29 & 4.01 & 5.21 & 2.23 & 10.40 \\
\hline 7 & $\mathrm{~L}$ & 54.71 & 22.09 & 0.23 & 1.14 & 3.49 & 4.72 & 1.50 & 11.48 \\
\hline 8 & $\mathrm{~T} 1$ & 52.01 & 19.36 & 0.22 & 1.21 & 4.07 & 4.73 & 1.62 & 11.40 \\
\hline 9 & & 70.29 & $>13.22$ & 0.18 & 1.20 & 1.44 & 0.99 & 0.99 & 5.77 \\
\hline Conc. limits $(\%)$ & & & & & & & &
\end{tabular}

${ }^{\star} \mathrm{ND}=$ Not detected

Table 9. Correlation coefficients between trace and major elements in soils of the study area

\begin{tabular}{|c|c|c|c|c|c|c|c|c|c|c|c|c|}
\hline & $\mathrm{V}$ & $\mathrm{Cr}$ & $\mathrm{Ni}$ & $\mathrm{Cu}$ & $\mathrm{Zn}$ & $\mathrm{SiO}_{2}$ & $\mathrm{Al}_{2} \mathrm{O}_{3}$ & $\mathrm{P}_{2} \mathrm{O}_{5}$ & $\mathrm{~K}_{2} \mathrm{O}$ & $\mathrm{CaO}$ & $\mathrm{MgO}$ & $\mathrm{Na}_{2} \mathrm{O}$ \\
\hline $\mathrm{Cr}$ & $0.97^{\star * *}$ & & & & & & & & & & & \\
\hline $\mathrm{Ni}$ & $0.97^{\star \star \star}$ & $0.96^{\star * *}$ & & & & & & & & & & \\
\hline $\mathrm{Cu}$ & $0.64^{* * *}$ & $0.71^{\star * *}$ & $0.68^{\star * *}$ & & & & & & & & & \\
\hline $\mathrm{Zn}$ & $0.73^{* * *}$ & $0.75^{* * *}$ & $0.77^{\star * *}$ & $0.68^{\star * *}$ & & & & & & & & \\
\hline $\mathrm{SiO}_{2}$ & 0.19 & 0.11 & 0.28 & 0.18 & 0.19 & & & & & & & \\
\hline $\mathrm{Al}_{2} \mathrm{O}_{3}$ & $0.4^{*}$ & -0.13 & $0.56^{\star * *}$ & -0.17 & -0.09 & $0.61^{\star * *}$ & & & & & & \\
\hline $\mathrm{P}_{2} \mathrm{O}_{5}$ & -0.33 & -0.35 & -0.26 & 0.29 & $0.49^{* *}$ & -0.06 & -0.22 & & & & & \\
\hline $\mathrm{K}_{2} \mathrm{O}$ & -0.25 & -0.32 & -0.19 & 0.32 & $0.56^{* * *}$ & 0.23 & -0.18 & $0.78^{\star * *}$ & & & & \\
\hline $\mathrm{CaO}$ & -0.23 & -0.15 & $-0.42^{\star \star}$ & 0.14 & -0.09 & -0.38 & $-0.69^{* * *}$ & 0.37 & 0.1 & & & \\
\hline $\mathrm{MgO}$ & -0.25 & 0.35 & 0.27 & 0.24 & 0.21 & $0.41^{*}$ & -0.03 & 0.14 & $0.39^{\star}$ & 0.08 & & \\
\hline $\mathrm{Na}_{2} \mathrm{O}$ & -0.1 & $0.40^{*}$ & -0.33 & -0.05 & -0.20 & -0.16 & -0.43 & -0.37 & -0.21 & 0.06 & -0.30 & \\
\hline $\mathrm{Fe}_{2} \mathrm{O}_{3}$ & $0.51^{\star \star}$ & -0.17 & $0.56^{\star * *}$ & -0.18 & -0.11 & 0.26 & $0.79^{\star * *}$ & -0.31 & -0.35 & $-0.55^{\star * *}$ & -0.07 & $-0.51^{\star \star \star}$ \\
\hline
\end{tabular}

Note: ${ }^{\star} \mathrm{P}<0.05,{ }^{* *} \mathrm{P}<0.01,{ }^{* * *} \mathrm{P}<0.001, \mathrm{n}=33$ soil samples 
from the Kfr Elzayat urban area (population in 1995 was 448,965). In terms of the distribution of heavy metals in the different physiographic units, the swales unit contained the highest values, as this is in Kfr El Zayat, which has many factories. We recommend that heavy metal contamination be studied within entire soil profiles and not just topsoils, because these metals affect soil and crop quality and can cause ground-water pollution. Protection against this hazard is vital for sustainable land management. Precise measures and efficient methods to improve soil and water quality must be conducted, in order to prevent soil and water pollution and to avoid the need for costly remediation in the future.

\section{References}

Abd Elgawad, M.; Hamdi, A. A.; Mahmoud, M. S.; Samir, I. G. 2007. Status of some heavy metals in Fayoum district soils, in 3rd Conference for Sustainable Agricultural Development, 12-14 November 2007, Fayoum, Egypt, 507-526.

Abdel-Moati, M. A. R.; El-Sammak, A. A. 1997. Man-made impact on the geochemistry of the Nile Delta Lakes. A study of metal concentrations in sediments, Water, Air and Soil Pollution 97(3): 413-429. http://dx.doi.org/10.1007/BF02407476

Abdel-Sabour, M. F.; Abdou, F. M.; Elwan, I. M.; Al-Salama, Y. J. 2002. Effect of soil contamination due to wastewater irrigation on Cr fractions in some soils of Egypt, in Proceedings of 6th Radiation Physics Conference, Assuit, Egypt, 27-30.

Abu Khatita, A. M. 2011. Assessment of soil and sediment contamination in the Middle Nile Delta area (Egypt)- Geo-Environmental study using combined sedimentological, geophysical and geochemical methods. Alexander-Universität ErlangenNürnberg zur Erlangung, Germany.

Abu, Z. M. 2011. Egyptian policies for using low quality water for irrigation. Water Resource Center, Egypt, Cairo.

Ali, A. A.; Moghanm, F. S. 2013. Variation of soil properties over the landforms around Idku Lake, Egypt, The Egyptian Journal of Remote Sensing and Space Sciences 16(1): 91-101. http://dx.doi.org/10.1016/j.ejrs.2013.04.001

Atwia, M. G.; Abou Heleika, M. M.; El-Shishtawy, A. M.; Sharp, J. M. 2006. Hydrostratigraphy of the Central Nile Delta, Egypt, using geoelectric measurements, EGS-AGU-EUG Joint Assembly, Nice, France 5: 6-11.

Baghdady, N. H.; Sippola, J. 1984. Extractability of polluting elements $\mathrm{Cd}, \mathrm{Cr}, \mathrm{Ni}$ and $\mathrm{Pb}$ of soil with three methods, Acta Agriculturae Scandinavica 34(3): 345-348. http://dx.doi.org/10.1080/00015128409435402

Baker, D. E.; Senft, J. P. 1995. Copper, in B. J. Alloway (Ed.). Heavy metals in soils. London: Blackie. http://dx.doi.org/10.1007/978-94-011-1344-1_8

Ball, D. F. 1964. Loss-on-ignition as estimate of organic matter and organic carbon in non-calcareous soils, Journal of Soil Science 15(1): 84-92. http://dx.doi.org/10.1111/j.1365-2389.1964.tb00247.x

Bohn, L. H.; McNeal, L. B.; O’Connor, A. G. 2001. Soil chemistry. $2^{\text {nd }}$ ed. New York: John Wiley.

Bowen, H. J. M. 1979. Environmental chemistry of the elements. London: Academic Press.
Bradl, H.; Xenidis, A. 2005. Chemical remediation techniques, in H. B. Bradl (Ed.). Heavy metals in the environment: origin, interaction and remediation. Amsterdam: Elsevier. http://dx.doi.org/10.1016/S1573-4285(05)80022-5

Brough, P. A. 1986. Principles of geographical information systems for land resources assessment. Oxford: Oxford University Press.

Climatologically normal for Egypt. 2011. The normal for El-Gharbia Governorate Station (1960-2011), Ministry of Civil Aviation: Meteorological.

Dawoud, M. A. 2004. Design of national groundwater quality monitoring network in Egypt, Environmental Monitoring and Assessment 96: 99-118.

http://dx.doi.org/10.1023/B:EMAS.0000031718.98107.eb

Dobos, E.; Micheli, E.; Baumgardner, M. F.; Biehl, L.; Helt, T. 2000. Use of combined digital elevation models and satellite radiometric data for regional soil mapping, Geoderma 97: 367-391. http://dx.doi.org/10.1016/S0016-7061(00)00046-X

Dobos, E.; Norman, B.; Bruce, W.; Luca, M.; Chris, J.; Erika, M. 2002. The use of DEM and satellite images for regional scale soil database, in 17th World Congress of Soil Science (WCSS), 14-21 August 2002, Bangkok, Thailand.

Dumont, H. J. 2009. A description of the Nile Basin, and a synopsis of its history, ecology, biogeography, hydrology, and natural resources, in H. J. Dumont (Ed.). The Nile: origin, environments, limnology and human use. New York: Springer. http://dx.doi.org/10.1007/978-1-4020-9726-3_1

Fanos, A. M. 2002. Report on the modified Mega Delta Workshop.

FAO. 2006. Guidelines for soil description. $4^{\text {th }}$ ed. FAO, Rome. ISBN 92-5-105521-1.

Govil, P. K.; Reddy, G. L. N.; Krishne, A. K. 2001. Contamination of soil due to heavy metals in Patanchera Industrial Development Area: Andra Pradesh, India, Environmental Geology 41: 461-469. http://dx.doi.org/10.1007/s002540100415

Gowd, S. S.; Reddy, M. R.; Govil, P. K. 2010. Assessment of heavy metal contamination in soils at Jajmau (Kanpur) and Unnao industrial areas of the Ganga Plain, Uttar Pradesh, India, Journal of Hazardous Materials 174: 113-121. http://dx.doi.org/10.1016/j.jhazmat.2009.09.024

He, J. Y.; Jia, X. 2004. Arc GIS geostatistical analyst application in assessment of MTBE contamination, in ESRI User Conference, Fremont, USA.

ITT. 2009. ITT Corporation ENVI 4.7 software. New York: White Plains.

Jankaite, A.; Vasarevičius, S. 2005. Remediation technologies for soils contaminated with heavy metals, Journal of Environmental Engineering and Landscape Management 13(2): 109-113.

Lagerkvist, J-S. B.; Oskarsson, A. 2007. Vanadium, in G. Nordberg, B. Fowler, M. Nordberg and L. Friberg, L. (Eds.). Handbook on the toxicology of metals. $3^{\text {rd }} \mathrm{ed}$. San Diego: Academic Press.

Lillesand, T. M.; Kiefer, R. W. 2003. Remote sensing and image interpretation. $2^{\text {nd }}$ ed. New York: John Wiley.

Lillesand, T. M.; Kiefer, R. W. 2007. Remote sensing and image interpretation. $5^{\text {th }}$ ed. New York: John Wiley.

Ling, W.; Shen, Q.; Gao, Y.; Gu, X.; Yang, Z. 2007. Use of bentonite to control the release of copper from contaminated soils, Australian Journal of Soil Research 45(8): 618-623. http://dx.doi.org/10.1071/SR07079 
Lu, S. G.; Bai, S. Q. 2010. Contamination and potential mobility assessment of heavy metals in urban soils of Hangzhou, China, Environmental Earth Sciences 60(7): 1481-1490. http://dx.doi.org/10.1007/s12665-009-0283-2

McLaughlin, M. J.; Zarcinas, B. A.; Stevens, D. P.; Cook, N. 2000. Soil testing for heavy metals. Communications in Soil Science and Plant Analysis 31(11-14): 1661-1700.

http://dx.doi.org/10.1080/00103620009370531

Ohnesorge, F. K.; Wilhelm, M. 1991. Zinc, in E. Merian (Ed.). Metals and their compounds in the environment, occurrence, analysis and biological relevance. Verlagsgesellschaft, Weinheim, Basel: VCH.

Rahman, S.; Khanam, D.; Adyel T.; Islam, M. Sh.; Mohammad Ahsan, A.; Akbor, M. A. 2012. Assessment of heavy metal contamination of agricultural soil around Dhaka Export Processing Zone (DEPZ), Bangladesh: Implications of seasonal variations and indices, Applied Sciences 2(3): 584-601. http://dx.doi.org/10.3390/app2030584

Raven, P. H.; Berg, L. R.; Johnson, G. B. 1998. Environment. $2^{\text {nd }}$ ed. New York: Saunders College Publishing.

Reimann, C.; de Caritat, P. 1998. Chemical elements in the environment. Berlin: Springer-Verlag. http://dx.doi.org/10.1007/978-3-642-72016-1

Romic, M.; Romic, D. 2003. Heavy metal distribution in agricultural top-soils in urban areas, Environmental Geology 43: 795-805.

Said, R. 1993. The River Nile: geology, hydrology and utilization. Oxford: Pergamon Press.

Shepard, D. 1968. A two-dimensional interpolation function for irregularly-spaced data. New York: ACM.

http://dx.doi.org/10.1145/800186.810616
Sundermann, F. W. (Jr.); Oskarsson, A. 1991. Nickel, in E. Merian (Ed.). Metals and their compounds in the environment; occurrence, analysis and biological relevance. Weinteim, Basel: $\mathrm{VCH}$.

Tong, S. T. Y. 1998. Indoor and outdoor household dust contamination in Cincinnati, Ohio, USA, Environmental Geochemistry and Health 20(3): 123-133. http://dx.doi.org/10.1023/A:1006561832381

USDA. 2010. Keys to soil taxonomy. $11^{\text {th }}$ ed. United States Department of Agriculture, Natural Resources Conservation Service (NRCS).

WHO. 1996. Trace elements in human nutrition and health. World Health Organization: Geneva.

Wong, M. H.; Wong, J. W. C. 1986. Effects of fly ash on soil microbial activity, Environmental Pollution A(40): 127-144. http://dx.doi.org/10.1016/0143-1471(86)90080-2

Woo, K. S.; Jo, J. H.; Basu, P. K.; Ahn, J. S. 2009. Stress intensity factor by $\mathrm{p}$-adaptive refinement based on ordinary Kriging interpolation, Finite Elements in Analysis and Design 45(3): 227-234. http://dx.doi.org/10.1016/j.finel.2008.10.002

Zeydan, B. A. 2005. The Nile Delta in a global vision, in 9th International Water Technology Conference, IWTC9 2005, Sharm El-Sheikh, Egypt, 31-40.

Zheng, C. 2006. Using multivariate analyses and GIS to identify pollutants and their spatial patterns in urban soils in Galway, Ireland, Environmental Pollution 142(3): 501-511. http://dx.doi.org/10.1016/j.envpol.2005.10.028

Mohamed S. SHOKR. Assistant Lecturer, received the degrees of B.Sc. and M.Sc from Tanta University, Egypt. Currently, he is Assistant Lecturer in the Soils and Water Department, Tanta University and has a scholarship from the Egyptian Government to complete part of his Ph.D. studies in the University of Wolverhampton, UK. His research activities are concerned with pedology, soil sustainability, remote sensing and GIS.

Ahmed A. EL BAROUDY. Received the degrees of B.Sc., M.Sc. and Ph.D. from The University of Tanta, Egypt. Currently, he is Assoc. Prof. of Soil in the Soil and Water Department of the University of Tanta. His research activities are mainly concerned with pedology, soil degradation, desertification, land evaluation, remote sensing and GIS modelling. He has published widely in Soil Science, having authored 21 refereed and conference papers.

Michael A. FULLEN. Professor Fullen received the degrees of B.Sc. and M.Sc. from The University of Hull (UK), a Ph.D. from the UK Council for National Academic Awards (CNAA) and a D.Sc. from The University of Wolverhampton. Currently, he is a Professor of Soil Technology at the University of Wolverhampton, UK. His research activities are mainly concerned with soil erosion, soil conservation, desertification and desert reclamation and his fieldwork is mainly based in Europe and Asia. He has published widely in Soil Science (as of March 2016, he has authored one book, 221 refereed papers, 217 conference papers and 26 consultancy reports). He is a referee for 48 journals and a member of the Editorial Board of 24 journals.

Talaat R. EL-BESHBESHY. Received the degrees of B.Sc., M.Sc. and Ph.D. from The University of Minia, Egypt. Currently, he is Professor of Soil Science and Plant Nutrition in the Soil and Water Department of the University of Tanta. His research activities are mainly concerned with plant nutrition, hydroponics, soil fertility and soil chemistry. He has published widely in Soil Science, having authored 25 refereed and conference papers.

Ramadan R. ALI. Professor of Soil Science at the National Research Centre, Cairo, since 1999. He was appointed as a Research Assistant in the Soils and Water Use Department. In 1993, he was awarded the degree of M.Sc. and was then appointed as Assistant Researcher. He obtained a PhD in 2013 and was then appointed as a Researcher. During 2003-2015 he published 56 scientific papers. He became Assistant Professor in 2008 and then Professor in 2014. He also participated in 24 research projects, published three book chapters and supervised several M.Sc. and Ph.D. degrees. 
Abd ELHALIM. Dr, received the degrees of B.Sc. and M.Sc. from The University of Tanta and a PhD from The University of Tanta through a scientific association with the University of Rostock, Germany. Currently, he is Assoc. Prof. of Soil Physics and Water Relations at the University of Tanta. His research activities are mainly concerned with soil physics, soil erosion, soil conservation, irrigation water management, evapotranspiration models and desert reclamation. He has published widely in Soil Science (he has authored 12 refereed papers and three conference papers).

Antonio J. T. GUERRA. Professor Guerra received the degrees of B.Sc. and M.Sc. from the Federal University of Rio de Janeiro (Brazil) and a PhD from King's College London (UK). He undertook his first Post-doctoral Fellowship at Oxford University (UK) and his second at the University of Wolverhampton (UK). Currently, he is Professor of Physical Geography at the Department of Geography, Federal University of Rio de Janeiro, where he co-ordinates LAGESOLOS (the Laboratory of Environmental Geomorphology and Soil Degradation). His research activities are mainly concerned with soil erosion, land degradation, soil rehabilitation and his fieldwork is mainly based in Rio de Janeiro and São Paulo States (Brazil). He has published nearly 100 papers in refereed papers in both Brazilian and international journals. He has coedited 17 books on geomorphology, soil erosion, environmental geomorphology, tourism, and soil rehabilitation in Brazil.

Maria C. O. JORGE. Received the degree of B.Sc. from the Federal University of Paraná (Brazil) and M.Sc. from the State University of Rio Claro (Brazil). Currently she is completing her PhD at the Federal University of Rio de Janeiro and she has just finished the sandwich component of her $\mathrm{PhD}$ at the University of Wolverhampton (2015). So far she has published 14 refereed papers in both Brazilian and international journals. She has also co-edited two books on land degradation and soil rehabilitation in Brazil. Her research activities are concerned with geotourism, geoconservation and geodiversity and her field work is conducted in Ubatuba Municipality, São Paulo State, Brazil. 